\title{
Retinoic acid induces expression of PA-FABP (psoriasis-associated fatty acid-binding protein) gene in human skin in vivo but not in cultured skin cells
}

Grønhøj Larsen F, Voorhees JJ, Åström A. Retinoic acid induces expression of PA-FABP (psoriasis-associated fatty acid-binding protein) gene in human skin in vivo but not in cultured skin cells.

Exp Dermatol 1994: 3: 212 218. Munksgalard, 1994

Abstract: PA-FABP (psoriasis-associated fatty acid-binding protein) is a new member of a group of low-molecular-weight proteins that are highly up-regulated in psoriatic skin and that share similarity to latty acid-binding proteins. In this study we demonstrate that PA-FABP transcripts are cxpressed in human skin in vivo and that topical application of $0.05 \%$ retinoic acid (RA) cream results in a rapid induction of PA-FABP transcripts following treatment for 16 hours and persists at increasing levels after 48 and $96 \mathrm{~h}$ of $\mathrm{RA}$ treatment. The PA-FABP mRNA response to $\mathrm{RA}$ was reduced by approximately $50 \%$ when patients concurrently were treated with RA and $0.025 \%$ clobetasol propionate (CLO) for 48 and $96 \mathrm{~h}$, whereas treatment with CLO alone resulted in PA-FABP transcript levels not significantly different from vehicle-treated skin. When comparing the effects of a well-known irritant, sodium lauryl sulfate (SLS), to those of RA and its vehicle, $0.05 \%$ RA cream but not $2 \%$ SLS in RA vehicle calused PA-FABP mRNA induction after $16 \mathrm{~h}$. SLS treatment of human skin for 96 h caused a slight increase in PA-FABP transcripts, but markedly less than that observed in response to RA treatment. Incubation of cultured human keratinocytes or skin fibroblasts with RA for up $1048 \mathrm{~h}$ did not significantly induce PA-FABP transcripts. Expression of PA-FABP message in keratinocytes was observed to be induced by calcium and fetal calf serum (FCS), while tetra-decanoyl phorbol acetate (TPA) caused little or no induction. Taken together, the marked inducibility of the PA-FABP gene is compatible with the possibility that this gene might be important in RA-mediated regulation of human skin growth and differentiation.

\author{
Frederik Gronhoj Larsen, \\ John J. Voorhees and \\ Anders Åström
}

Department of Dermatology. University of Michigan, Ann Arbor, Michigan, U.S.A.
Key words: retinoic acid - gene regulation fibroblasts - keratinocytes

Frederik G. Larsen, MD, Department of Dermatology, Bispebjerg Hospital, 2400 Copenhagen NV., Denmark.

Accepted for publication 11 July 1994

\section{Introduction}

The fatty acid-binding proteins (FABPs) belong to a multigene family of low molecular weight cytoplasmic binding proteins $(\approx 14-15 \mathrm{kDa})$ that bind fatty acids, and are abundantly expressed in tissues specialized in the synthesis, transport, storage and utilization of fatty acids. Their putative main physiological significance is the assurance that long-chain fatty acids and derivatives, either in iransil through membranes or present in intracellular compartments, are largely complexed to proteins (1). Also, since recent data indicate the involvement of fatty acids and fatty acid derivatives (c.g., eicosanoids) in cellular growth and differentiation and signal transduction pathways, their respective binding proteins may also function in these complex processes $(2,3)$.

The epidermis is a specialized tissue of lipid metabolism, but cannot synthezise some of the fatty acids (i.e., linoleic acid, arachidonic acid) that are important for epidermal growth and barrier functions (4). Thus, fatty acid transport in the skin and its metabolism may be facilitated by FABPs. In 


\section{PA-FABP regulation in human skin and cultured skin cells}

fractionated non-cultured psoriatic keratinocytes there is evidence of an altered fatty acid transport and metabolism which is in line with the dramatic up-regulation of a group of FABPs including psoriasin, calgranulin A and $B$, and cystatin $A(5,6)$. Recently, Madsen et al. (7) identified a new member of this group that is highly up-regulated at the message and protein levels in non-cultured psoriatic keratinocytes and termed it PA-FABP (psoriasis-associated fatly acid-binding protein). However, nothing is known about PA-FABP gene expression and regulation in human skin. The main purpose of the present study was to examine the regulation of PA-FABP gene expression in human skin in vivo as well as in cultured skin cells. Since topical retinoic acid can cause an erythematous reaction clinically similar to irritant dermatitis (810), an important issue is the extent to which alterations induced by RA are caused by its irritant properties or by more physiologically relevant mechanisms. Therefore, we have also examined the effects of the irritant sodium lauryl sulfate (SLS) as well as the anti-inflammatory compound clobetasol propionate (CLO) on expression of PA-FABP.

\section{Material and methods}

Polymerase chain reaction (PCR) and c $D N A$ cloning

PCR was carricd out in an automated Perkin-Elmer Cetus thermocycler using $1 \mu \mathrm{g}$ of total RNA extracted from keratome biopsies of psoriatic skin. RNA was reverse transcribed into a complementary DNA using reverse transcriptase $(2.5 \mathrm{U})$ and oligo d(T) 16 as primers $(2.5 \mu \mathrm{M})$, at $42^{\circ} \mathrm{C}$ for 25 min, in a total volume of $20 \mu \mathrm{l}$ buffer $(5 \mathrm{mM}$ $\mathrm{MgCl}_{2}, \quad 1 \times$ reaction buffer as supplied by the manufacturer, $1 \mathrm{mM}$ dXTP, $1 \mathrm{mM}$ RNase inhibitor) overlaid with $70 \mu \mathrm{l}$ of mineral oil (Gene Amp. RNA Kit, Perkin Elmer Cetus, CT, USA). Thirtyfive cycles of PCR amplification $\left(95^{\circ} \mathrm{C}, 1 \mathrm{~min}\right.$, $50^{\circ} \mathrm{C}, 1 \mathrm{~min}, 72^{\circ} \mathrm{C}, 1 \mathrm{~min}$ ) were performed in 100 4 l using Ampli Taq DNA polymerase $(2.5 \mathrm{U}), 2.6$ $\mathrm{mM} \mathrm{MgCl}, 1 \times$ reaction buffer, and $0.15 \mu \mathrm{M}$ (final concentration) of each primer as suggested by the manufacturer. The oligonucleotide primers were synthesized by the University of Michigan DNA core lacility and based upon a previously published cDNA sequence (7). Each primer had 25 nucleotides hybridizing to its template and at its 5'end, a restriction site and 6 additional nucleotides that facilitate complete digestion with the restriction enzymes. Eco RI and Bam HI sites were conlained in the forward and reverse primers, respectively. The primers were designed so as to amplify the coding region and were as follows:
Forward: 5'-gttlccgatte A C C G C C G A C G C AGACCCCTCTCTGC - $3^{\prime}$

Reverse: 5'-caalaccggatccGGGATGATCCTAATTAATCCAACAC-3'

The length of the amplified DNA was determined on a 1.5\% agarose gel. The amplified 633-bp region of PA-FABP was isolated from the gel. ethanol precipitated and subcloned into plasmid pSG5 (Stratagene. Lal Jolla, CA, USA).

\section{Skin biopsies}

For in vivo treatment, $0.05 \%$ retinoic acid cream. its vehicle (Ortho Pharmaceuticals, Raritan. NJ. USA) or $0.025 \%$ clobetasol propionate (CLO) ointment (Glaxo Dermatology. NC. USA) was applied once as $3 \times 9 \mathrm{~cm}$ patches to buttock skin and maintained under plastic wrap for 24 . 48 , or $96 \mathrm{~h}$ prior to biopsy. When patients concurrently were treated with RA and CLO equal amounts of $0.1 \%$ RA and $0.05 \%$ CLO (approximately $250 \mathrm{mg}$ of each) were mixed and applied to the skin. Subjects were also treated for 16 or $96 \mathrm{~h}$ under occlusion with 2\% "SLS. SLS was obtained from E.1. Dupont De Nemours \& Company (Wilmington, DE. USA) and compounded at $2 \%$ in RA vehicle cream. After obtaining written informed consent. keratome biopsies consisting primarily of epidermis (11) were procured from the treated areas using $1 \%$ plain lidocaine as a local anesthetic. Epidermal keratomes were immediately frozen in liquid nitrogen and stored at $-70^{\circ} \mathrm{C}$ until use. All subjects provided written. informed consent and all procedures were performed under approval of the University of Michigan Medical Center Institutional Review Board.

\section{Coll culture}

Human keratinocytes were purchased from Clonetics and expanded to about $50 \%$ confluency in $150-\mathrm{mm}$ tissue culture dishes in a low $\mathrm{Ca}^{++}$ $(0.15 \mathrm{mM})$, serum-free keratinocyte growth medium (KGM) containing epidermal growth factor (EGF) $(0.1 \mathrm{ng} / \mathrm{ml})$, insulin $(5 \mu \mathrm{g} / \mathrm{ml})$, hydrocortisone $(0.5 \mu \mathrm{g} / \mathrm{ml})$, bovine pituitary extract. gentamicin $(50 \mu \mathrm{g} / \mathrm{ml})$, and amphotericin-B $(50 \mathrm{ng} / \mathrm{ml})$ (Clonetics, San Diego, CA. USA). The effect of glucocorticoid wals examined after the medium was replaced with hydrocortisone-free KGM medium $48 \mathrm{~h}$ prior to treatment. Cells were treated up to $48 \mathrm{~h}$ with $1 \mu \mathrm{M}$ RA or calcium $(2 \mathrm{mM})$ or with FCS $(10 \%)$ or TPA (20 nM).

Human dermal fibroblasts were also used in this study. They were prepared from punch biopsies of buttock skin (12) and propagalted in Dulbecoss 


\section{Grønhøj Larsen et al.}

modified Eagle's medium containing 10\% fetal calf serum (FCS), $100 \mathrm{U} / \mathrm{ml}$ of penicillin, and $100 \mu \mathrm{g} /$ $\mathrm{ml}$ of streptomycin. Cells were then grown to confluency in 150-mm tissue culture dishes (Corning Glass Co., Corning, NY, USA) and treated for up to $48 \mathrm{~h}$.

Cells were maintained in a humidified incubator at $37^{\circ} \mathrm{C}$ with $5 \%(1) \mathrm{CO}_{2} / 95^{\prime} / 0$ air. When cells were treated with $\mathrm{RA}$, they were protected from light during the incubation period. Experiments were conducted on cells in the third through sixth passage.

\section{Northern analysis of $m R N A$}

RNA was isolated from cultured human skin fibroblasts, keratinocyles or frozen keratome biopsies by guanidinium isothiocyanate lysis and ultacentrifugation as previously described (13). Briefly, RNA concentrations were determined by absorbance at $260 \mathrm{~nm}$ and equal quantities of total RNA were electrophoretically separated in $1 \%$ formaldehyde-agarose gels containing $0.5 \mu \mathrm{g} /$ $\mathrm{ml}$ ethidium bromide. Twenty micrograms total RNA was transferred to derivatized nylon membranes (Zeta-Probe, Bio-Rad, Richmond, CA, USA). Filters were baked $2 \mathrm{~h}$ at $80^{\circ} \mathrm{C}$ in vacuo, then prehybridized for $2-4$ h at $42{ }^{\circ} \mathrm{C}$ in $50 \%$ formamide. $5 \times \mathrm{SSC}(1 \times \mathrm{SSC}=150 \mathrm{mM} \mathrm{NaCl}, 15 \mathrm{mM}$ sodium citrate), $50 \mathrm{mM}$ sodium phosphate, $\mathrm{pH}$ 7.0, $1 \times$ Denhardt's solution, $250 \mu \mathrm{g} / \mathrm{ml}$ yeast IRNA, $100 \mu \mathrm{g} / \mathrm{ml}$ sonicated herring sperm DNA, and $1 \%$ SDS. Hybridization was carried out for $18 \mathrm{~h}$ at $42^{\circ} \mathrm{C}$ in the same buffer. Blots were sequentially hybridized against 32 -labeled PAFABP and cyclophilin (14) probes prepared by random priming. Quantitation of mRNA levels was performed using a phosphorimager (Molecular Dynamics, Sunnyvale, CA, USA), and PAFABP message levels were normalized to cyclophilin. Filters were washed once in $0.2 \times \mathrm{SSC}, 0.1 \%$ SDS at room temperature, then twice for $15 \mathrm{~min}$ in $0.2 \times \mathrm{SSC}, 0.1 \% \mathrm{SDS}$ at $56^{\circ} \mathrm{C}$ and finally once for $15 \mathrm{~min}$ in $0.1 \times \mathrm{SSC}, 0.1 \% \mathrm{SDS}$ also at $56^{\circ} \mathrm{C}$. An adult Multiple Tissue Northern Blol wals purchased from Clontech Lab., Inc. and contained 2 $\mu g$ in each lane of highly pure poly $(\mathrm{A})^{-1}$ RNA from 8 different tissues. Autoradiography was performed using intensifying screens at $-70^{\circ} \mathrm{C}$.

\section{Statisticis}

For each duration of time (i.c. 16, 24, 48, and 96 h) the -fold induction was compared to unity by a one-sample t-test. All p-values are two-tailed.

\section{Results}

Expression of PA-FABP mRNA in human skin in vivo

PA-FABP transcripts were detectable in untreated skin (data not shown) as well as skin treated with vehicle (Fig. 1). As shown in Fig. 1. PA-FABP mRNA was markedly and significantly increased by RA treatment compared to vehicle-treated skin at all time points studied (24,48, and $96 \mathrm{~h}$ ). Induction was observed ats early as 16 h after topical RA tralment (mean 2.0-fold \pm 0.23 SEM, $p=0.006$, $n=7$ ) (data not shown) with increasing values following treatment for $24 \mathrm{~h}$ (mean 2.8 -fold \pm 0.34 SEM, $\mathrm{p}=0.006$ ), 48 h (mean 8.2-fold \pm 2.5 SEM. $\mathrm{p}=0.04$ ). and $96 \mathrm{~h}$ (mean 17.3-fold \pm 5.5 SEM, $\mathrm{p}=$ $0.03)$. However, a considerable inter-individual variation in -fold induction existed both at 48 (range 3 to 18) and 96 h (range 5 to 34). At these time points the induction of PA-FABP $\mathrm{mRNA}$ by RA was reduced by approximately $50 \%$ when palients concurrently were treated with $R A$ and CLO. Treatment with CLO alone resulted in PAFABP transcript levels not significantly dilferent from vehicle-treated skin.

The treatment sites were assessed for erythema

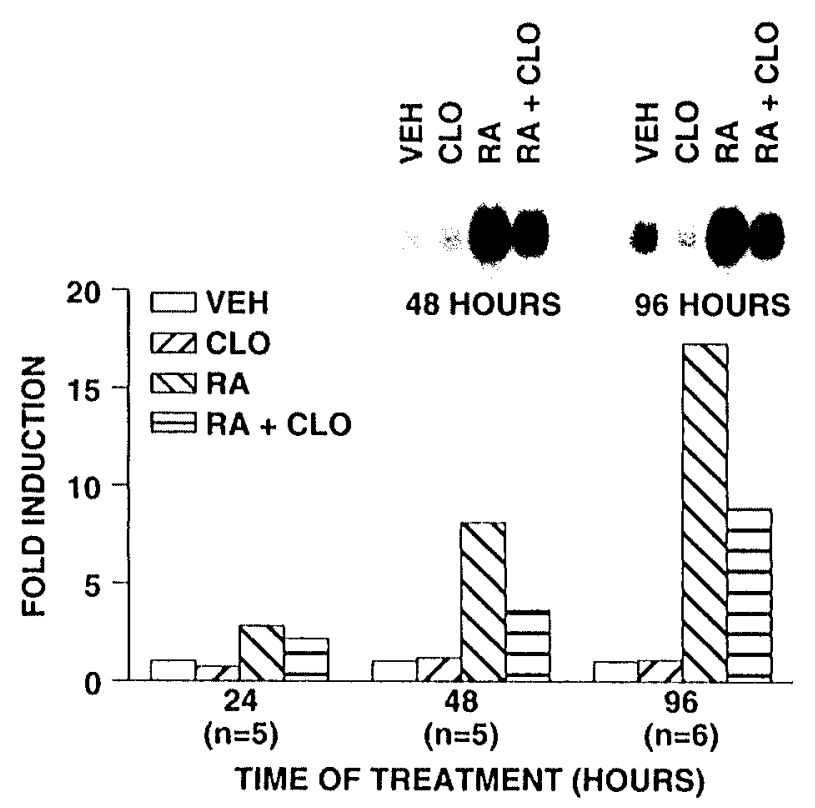

Figrare I. a) Induction of PA-FABP mRNA in human skin by topically applied retinoic acid cream (RA). Each volunteer wals treated wilh $0.05 \%$ RA, its vehicle. $0.025 \%$ clobetasol propionate dintment (CLO), or RA and $\mathrm{CLO}$ in combination under occlusion for the times indicated prior to biopsy. " is the number of RA, CLO or RA/CLO treated patients oblained at each time point. b) alutoradiographic bands from two representative experiments following treatment for 48 and $96 \mathrm{~h}$. 
using a (0-9 scale, 0 representing absent, and 9 maximal erythema (10). However, there was no correlation between degree of erythema and fold induction by RA.

\section{Effect of sodium lanry sulfate on PA-FABP expression in human skin in vivo}

The above data clearly demonstrate that PA-FABP expression is increased in skin treated with topical RA. To determine whether this response was specific to RA, biopsies were oblained from subjects treated with the irritant sodium lauryl sulfate (SLS) prepared in retinoic acid vehicle for 16 or 96 h under occlusion. Both 2"\% SDS and $0.05 \%$ RA produced a marked increase in erythema relative to vehicle after $96 \mathrm{~h}$, which was comparable between the two agents. Little or no erythema was observed in response to vehicle after $96 \mathrm{~h}$, nor to any of the treatments after $16 \mathrm{~h}$. In 7 patients treated with SLS or RA cream for $16 \mathrm{~h}$. PA-FABP transcripts were not significantly induced compared to vehicle following SLS treatment (mean 0.96-fold $\pm 0.06, p=0.54$ ). while as mentioned above RA treatment resulted in a significant induction. Also, the induction of PA-FABP mRNA by SLS after treatment for $96 \mathrm{~h}$ was markedly less than that obtained in response to RA (Fig. 2).

\section{Expression of PA-FABP in human keratinocyles and fibrohlasts}

Because RA induced PA-FABP mRNA in viro, it was of interest to determine whether an induction also occurred in cultured human keratinocytes. Subconfluent cultures of keratinocytes were harvested. RNA extracted, and PA-FABP mRNA

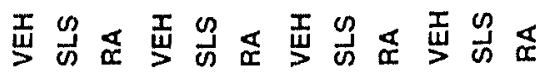

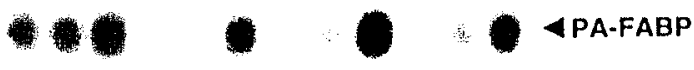

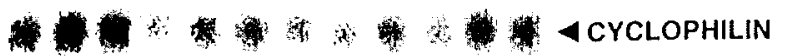

Figrar' 2. Induction of PA-IABP mRNA in human skin by topically applied sodium lauryl sulfate (SLS) or retinoic acid cream (RA). Four individuals were treated for $96 \mathrm{~h}$ under occlusion with velicle (V), 2\% SLS, or $0.05 \%$ RA. Total RNA (20 $\mu$ per lane) was successively filter hybridized with p-labeled cDNA probes for PA-FABP and cyclophilin.

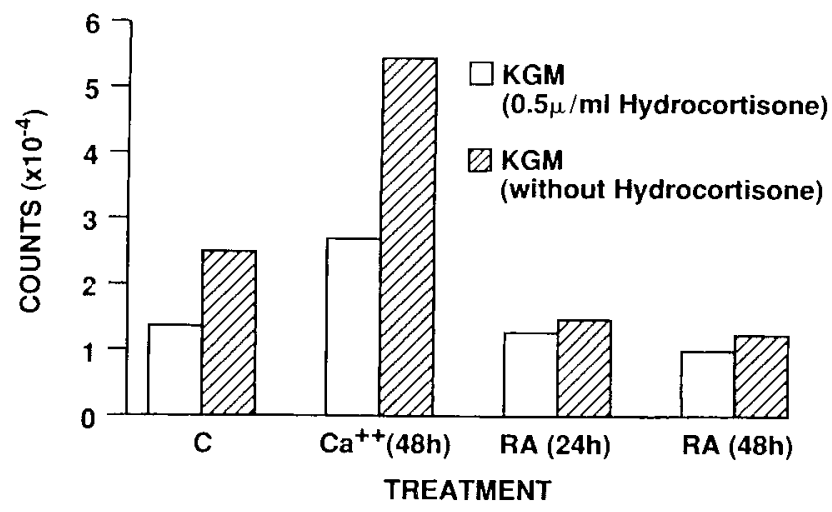

Figme 3 . Induction of PA-I:ABP mR NA by calcium (CA ) ? $\mathrm{mM})$ and retinoic acid $(\mathrm{R} A)(1 \mu \mathrm{M})$ in normal adule human keratinocytes. When cells were $50^{\mathrm{m}}$, contluent. ther were either mantained in hadrocortisone-containing K(iM (Cloneties) growth media or the media were repliked with hydrocortisone-

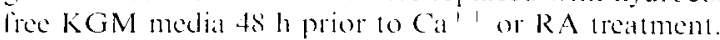

levels were determined. In untreated keratinocytes, PA-FABP mRNA was at a low but detectable level. Treatment of keratinocytes by RA for 24 or $48 \mathrm{~h}$ did not induce PA-FABP mRNA when cells were grown in the presence or absence of hydrocortisone (Fig. 3). When grown in the presence of hydrocortisone, markedly lower transeript levels were observed in both unstimulated (control) and stimulated cells. Treatment with calcium for $48 \mathrm{~h} \mathrm{re-}$ sulted in an approximately 2-fold induction of PAFABP transcripts. In a separate experiment. incubation of keratinocytes with FCS (10\%) for $48 \mathrm{~h}$ also induced PA-FABP gene expression $(\approx 3$-fold). while TPA (20 nM) had little or no inducible elfect (data not shown). Induction of PA-FABP expression by $R A$ was also determined in fibroblasts. In these cells, transcripts were undetectable both in untreated cells and in eells after treatment with RA ( $1 \mu \mathrm{M})$ for 24 and 48 h (data not shown).

\section{Presence of PA-FABP mRNA in aduht human tisisuch's}

To determine the tissue distribution of PA-FABP gene expression. poly $(A)^{+} R N A$ from various adult human tissues wats analyzed (Fig. 4). Of the tissues examined. heart and placenta had a high level of PA-FABP mRNA, while brain. lung, skeletal muscle and pancreas hald moderate levels. In liver and kidney tissue levels of PA-FABP transcripts were not detectable.

\section{Discussion}

Low-molecular-weight FABPs are abundant (i.e. $12 \%$ of cytosolic protein) in tissues that are active 

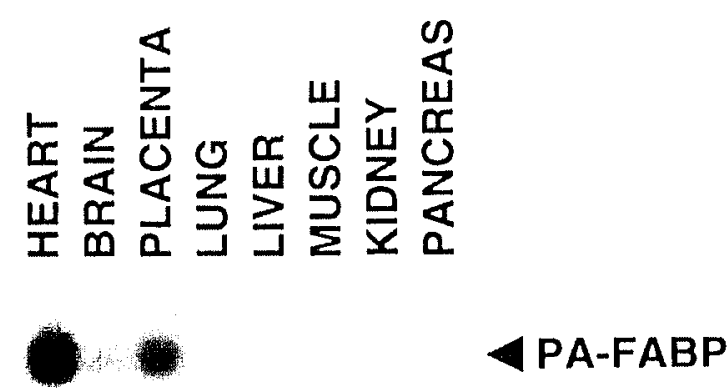

Figure 4. Lxpression of basal PA-JABP mRNA levels in various adult human tissues.

in fatty acid synthesis, transport, storage, or utilization $(15,16)$. Whereas the lipid metabolic activity might predict the presence of cytosolic FABPs in epidermis, available data are conflicting. Thus, Schurer et al. (17) found that cytosol from epidermis in vivo and in vitro showed no latty acid binding activity within the molecular weight range ( 12 $14 \mathrm{kDa}$ ) of these conventional FABPs. However, Siegenthaler et al. (18) characterized an E-FABP (15 kDa) in human epidermal cells that binds oleic acid with high alfinity but does not bind all-trans-, 13-cis-and 9-cis-retinoic acid nor all-trans-retinol. They also showed that expression levels of E-FABP were low in normal epidermis, higher in human cultured keratinocytes and still higher in psoriasis. Recently, Madsen et al. (7) also identified a protein (PA-FABP) with homology to other members of the FABP family, that was highly up-regulated in psoriatic skin. Whether PA-FABP and E-FABP are the same or different proteins remains to be investigated.

We have previously cloned and investigated the regulation of a human retinoic acid binding protein (CRABP-II), which is a member of the hydrophobic ligand binding family of proteins that includes FABPs and CRBPs $(13,19,20)$ ). It has been shown that (RABP-II is highly inducible by RA and is also overexpressed in psoriasis $(13,1921)$. For this reason we determined whether PA-FABP also was regulated by $R A$. Interestingly, PA-FABP mRNA was induced following RA treatment for $16 \mathrm{~h}$, whereas no induction was observed, compared to vehicle-treated skin, following SLS treatment for the same period of time. Despite the induction of marked erythema by both SLS and RA after treatment for $96 \mathrm{~h}$, the induction of PAFABP mRNA by SLS wals markedly less than that oblained in response to RA (Fig. 2). It hals previously been shown that SLS and RA elicit a similar clinical and histologic response following treatment for $96 \mathrm{~h}(9)$. Also, a time-course comparison demonstrated that RA induced epidermal thickening, stratum corneum compaction, spongiosis, and mitotic figures more rapidly than did SLS (22). Taken logether, these findings indicate differing mechanisms of actions of the two agents, and that the PA-FABP mRNA induction by RA in human skin in vivo camnot be accounted for by irritant eflects. A similar effect of RA and SLS on CRABP-II mRNA levels in human skin in vivo has also been demonstrated (10).

Glucocorticoids are effective for the treatment of various inflammatory skin diseases including psoriasis. Retinoids exert an opposite effect compared to glucocorticoids and cause hyperplasia of the skin when applied topically $(9,22)$. It has been shown that retinoids can reverse glucocorticoid-induced atrophy in humans and mice. while the antiinflammatory property of glucocorticoids is not alfected $(23,24)$. It was therefore of interest to investigate the effects of glucocorticoids on PAFABP expression. We found that CLO opposed the eflect of RA-induced PA-FABP expression in human skin in vivo (Fig. 1). Whether this effect of CLO on PA-FABP expression is due to a dired down-regulation of the gene by the glucocorticoid receptor or is a secondary effect remains to be investigated. It was, however, clear from the in vitro experiment that PA-FABP transcripts were markedly lower in both unstimulated and stimulated keratinocytes when grown in the presence of hydrocortisone, which favors the possibility that glucocorticoids directly down-regulate the PAFABP gene (Fig. 3)

Exposure of keratinizing cells to retinoids has been shown to inhibit the normal sequence of keratin expression (25) and cornified envelope formation (26). The extent of keratinocyte differentiation can be enhanced under submerged conditions, when the keratinocytes are cultured in the presence of delipidized serum to reduce the level of RA (25). Furthermore, addition of RA at micromolar concentrations to submerged cultures grown in RA-depleted medium induces marked changes in lipid synthesis and lipid composition with a decreased cholesterol sulfate production (27) and leads to a complete suppression of acylceramide and lanosterol synthesis (28). Our findings that treatment of subconfluent cultures of keratinocytes with RA for up to 48 h showed unaltered or a tendency towards decreased PA-FABP mRNA levels as compared with basic levels might thus possibly reflect an altered lipid metabolism (Fig. 3). In contrast to RA, when grown at physiological calcium concentrations, keratinocytes display a markedly higher capacity to differentiate. Also, both involucrin content and transglutaminase activity, two key determinants of cornified en- 


\section{PA-FABP regulation in human skin and cultured skin cells}

velope during terminal differentiation, are accelerated and begin to occur prior 10 confluence when the extracellular calcium concentrations a re raised to physiological levels (29). PA-FABP mRNA was found to respond to both external calcium ( $2 \mathrm{mM}$ ) (Fig. 3) and FCS (10\%) (data not shown) which favors the concept that the stratified structure of the epidermis and/or the presence of dermis is an important determinant of PA-FABP regulation in rivo. Taken logether, our findings are in accordance to those of Madsen et al. (7) who found that, under conditions that promoted incomplete terminal differentiation (10\% FCS), PA-FABP and a few other proteins were strongly up-regulated.

Although the FABPs have functional similarities, their amino acid sequences are unique for each tissue type: but across species the FABP of a specific tissue has a highly conserved amino acid sequence. The tissues containing the most abundant quantities of the FABPs are found in liver (3\%) of cytosol protein), intestine (1-2\% of cylosol protein), and heart muscle (5\% of cylosol protein) (30). Using a PAGE-autoradioblotting technique. Siegenthaler et al. (I8) demonstrated that liver-, intestine-, and heart- when compared to E-FABP showed distinct mobilities, suggesting that the primary structure of E-FABP may be different in these tissue. The study also showed that E-FABP was detectable in adipose tissues. The present study reveals that PA-FABP mRNA expression is not restricted to epidermal cells since high or moderate message levels were detected in heart, placenta, brain, lung, skeletal muscle and pancreas.

In conclusion, the main findings of the present study show that PA-FABP is regulated by $R A$ in human skin in viro but not in cultured keratinocytes or skin fibroblasts. We also demonstrate that PA-FABP mRNA induction by RA in human skin camnol be explained by its "irritint" properties since PA-FABP mRNA induction after $96 \mathrm{~h}$ is markedly less following topical application of the irritant SLS than that obtained in response to topical RA treatment. Although PA-FABP was named such because it is highly up-regulated in psoriatic keratinocytes the present study shows that it is simply an RA-regulated FABP found both in skin and several other tissues.

\section{Acknowledgments}

This work wats supported by the R.W. Johnson Pharmaceutical Researeh Institute and the Babcock Research Lindowment. Firederik Gronhoj Larsen was supported by the Danish Miedical Research Council (Grant 12-0620-1) and the Leo Foundation. Denmark. Anders Aström was the recipient of a Dermatology Foundation Career Development Award.

\section{References}

1. Glatz J I: Vork M M. Cistola D P. ran der Vusse G J Cytoplasmic latty acid binding protein: Signilicance for intracellular transport of fally alcids and putative role on signal transduction pathways. Prostaglandins Leutor Fssent Fally Acids 1993: $48: 3341$.

2. Dennis E A. Rhee S G. Billah M M. Hannum Y A. Role of phospholipase in generating lipid sceond messengers in signal transduction. FASI:B 1991: 5: 2008 : 2077.

3. James G, Olson E N. Fatly acylated proteins as components of intracellular signaling pathway's. Biochemistry 1990 : 29: 2623.2634

4. Chan C-C. Duhamel L. Ford-Hutchison A. Leukotriene Bt and 12-hydroxyeicosatelatenoic acid stimulate epidermal proliferation in vivo in the gainea pig. I Inest Dermathol $1985: 85: 333334$

5. Madsen P. Rasmusien H H, Lellers H. el al. Molecular cloning. occurrence. and expression of a novel partially secreted protein "psoriasin" that is highly up-regulated in psoriatic skin. I Invest Dermatol 1991: 97: $701-712$.

6. Celis J L. Madsen P. Rasmusson H H. et al. A comprehensive (wo-dimensional gel protein database of non-cultured unliactionaled human epidernal keratinocytes: towalds an integrated approach to the study of eell proliferation, difrerentiation and skin discases. Electrophoresis 1991: 12: 802872

7. Madsen P. Rasmussen H H. leffers H. Honore B. Celis J L Molecular cloning and expressing of a novel keratinosyce protein (psoriasis-issociated fally acid-binding protein [PA-FABP]) that is highly up-regulated in psorlatio skin and that shates similarity to fatty acid-binding proteins. I Invest Dermatol 1992: 90): 299 305

8. Weiss J S. Ellis C N. Headington J T. Tincoff T. Hamilton T A. Voorhees I J. Topical tretinoin improves photoaged skin. A double-blind wehicle controlled study. JAMA 19ss: 259: $527-532$

9. Fisher $G$ J. Limam I. Grilliths ( E M. at al. Collular. immunologic and biochemical chatacterization of topical retinoic acid-treated human skin. J Invest Dermatol 1991 96: 699) 707.

10. Elder I T. Cromic M A. Grifthis ( I: M. Chambon P. Voorlaces J J. Stimulus-selective induction of CRABP mRNA: A matker for retinote acid action in human skin J Invest Dermatol 1993: 100: 356 350.

11. Voorhees J J. Duell E A. Bass L J, Powell J A. Harrell E R. Decreased cyclic AMP in the epidermis of lesions of psoriasis. Arch Dermatol 1972: 105:695701

12. Harper R A. Grove (3. Iluman skin fibloblasts derived from papillary and reticulat dermis: differences in growth potential in vitro. Science 1979: 204: $526 \quad 527$

13. Aström A. Tavakkol A. Pencrsson U. Cromic M. likder I T. Voorlees J J. Molecular cloning of two humbn cellulat retinoic acid-binding proteins (CRABP). I Biol (hem l99): 206: $17602 \quad 176060$

14. Elder J T. Fisher G J. Zhang Q Y. el al. Retinoic acid receptor gene expression in human skin. J Invest Dermatol 1991: 96: $425+33$

15. Bass N M. Function and regulation of hepatic and intesti nal latly acid binding protcins. Chem Phys Lipids 1955: 38: 95114

16. Kaikaus R M. Bass N M. Oeknel R K. Functions of fally acid-binding proteins. Experientia 1990: 46:617-630.

17. Schurer N Y, Bass N M. Jin S, Manning J A. Pillai S. Willi ams M L. High-affinity latty acid-binding activity in epidermis and eultured keratinocyles is attributable to highmolecular-weight and not low-molecular-weight fant acidbinding proteins. I lowest Dermalol 1993: 100: 82 so.

18. Siegenthater G. Ilow R. Chatellard-Gruaz D. Jakoni S. 


\section{Gronhoj Larsen et al.}

Saturat J H. Characterization and expression of a novel human fatty acid-binding protein: The epidermal type (EFABP). Biochem Biophys Res (omm 1993: 190: 482 2887.

19. Piletta P, Saurat J-H. Cellular retinoic acid-binding proteins (CRABP). Exp Dermatol 1993: 2: 191 -195.

20. Pilctta P, Jaconi S, Siegenthaler G, Didierjean L, Saurat JH. Topical glucocorticosteroids modulate the expression of CRABP I and CRABP II in human skin differently. Exp Dermatol 1994: 3: 23 28.

21. Elder J T, Aström A. Pettersson U, et al. Differential regulation of retinoic acid receptors and binding proteins in human skin. J Invest Dermatol 1992: 98: 673-679.

22. Griffiths C E M. Finkel L J, Tranfaglia M G, Hamilton T $A$, Voorhees J J. An in vivo experimental model for effects ol topical retinoic acid in human skin. Br J Dermatol 1993: 129: $389-394$.

23. Lesnik R H, Mezick J A. Capetola R, Kligman L H. Topical all-trans-retinoic acid prevents corlicosteroid-induced skin atrophy without abrogating the anti-inflammatory effect. J Am Acad Dermatol 1989: 21: 186-190.

24. De Laceharriere O, Escoffier C. Gracia A M. et al. Reversal effects of topical retinoic acid on the skin of kidney transplant recipients under systemic corticotherapy. J Invest Dermatol 1990: 95: $516 \quad 522$.
25. Fuchs $E$, Green H. Regulation of terminal differentiation of cultured keratinocytes by vitamin A. Cell 1981: 25:617. 625.

26. Green H, Watl F. Regulation by vilamin A of envelope cross-linking in cultured keratinocytes derived lrom different human epithelia. Mol Cell Biol 1982: 2: 11151117.

27. Jetten A M, George M A, Nervi C, Boone L R, Rearick J 1. Increased cholesterol sulfate and cholesterol sulfotransferase activity in relation to the multi-step process of differentiation in human keratinocytes. J Invest Dermatol 1989: 92: 203-209.

28. Brod J, Bavelier E, Justine P. Weerheim A, Ponec M. Acylceramides and lanosterol-lipid markers of terminal differentiation in cultured human keralinocyles: modulating offect of retinoic acid. In Vitro Cell Dev Biol 1991: 27A: 163 168.

29. Pillai S, Bikle D D, Mancianti M L, Cline P, Hincenbergs M. Calcium regulation of growth and differentiation of normal human keratinocyles: modulation of differentiation competence by stages of growth and extracellular calcium. J Cell Physiol 1990: 143: 294-302.

30. Bass $N$ M. The cellular fatty acid binding proteins: Aspects of structure, regulation, and function. Int Rev Cyt 1988: 111: 143-184. 
This document is a scanned copy of a printed document. No warranty is given about the accuracy of the copy. Users should refer to the original published version of the material. 